\title{
МІЖДИСЦИПЛІНАРНИЙ ДИСКУРС
}

DOI: $10.31861 /$ pytlit2019.99.180

УДК 821.133.1-31.Mep.09

\section{СИСТЕМА НАВЧАННЯ ЯК СОЦІАЛЬНА ПРОВОКАЦІЯ: ЗА РОМАНОМ Р. МЕРЛЯ „ЗА СКЛОМ”}

\author{
Катерина Федорівна Калинич \\ orcid.org/0000-0002-8263-6322 \\ katerin1210@ukr.net \\ Аспірантка
}

Кафедра зарубіжної літератури, теорії літератури та слов'янської філології

Чернівецький національний університет імені Юрія Федьковича Вул. Коцюбинського, 2, 58012, м. Чернівці, Україна

Анотація: Розглянуто причини студентських протестів 1968 року. Увага акцентується на передумовах виникнення французької травневої революції. Досліджено роман Р. Мерля „За склом” (1970) у ключі вузівської системи навчання. Визначено причиннонаслідковий процес соціальних подій в аспекті архаїчної традиції викладання у системі вишівського навчання Франції XX ст. Простежено, що назрілість термінового оновлення навчальних програм, лекційних та семінарських занять спровокувала бунтарські настрої студентів. Зроблено висновок, що студентські заворушення 1968 р. не лише змінили соціально-економічну сферу французького суспільства, а й суттєво оновили систему вишівського викладання.

Ключові слова: Р. Мерль, „За склом”, викладач, студент, студентські протести 1968 р., криза, вища освіта.

В університетському житті багатьох країн 1968 рік ознаменувався рядом кризових станів, супроводжуючись студентськими протестами. Саме у вишівському середовищі визрівало розуміння розриву між соціальною реальністю та ідеалізованим змістом суспільних й аксіологічних парадигм. Виступи

(C) Калинич К., 2019 
студентів проти „істеблішменту” виражали не лише незадоволеність діяльністю тодішньої влади та внутрішніх університетських порядків, але й загальне розчарування у цивілізаційних принципах Нового часу [2, с. 371-372]. Вважається, що молодь найпершою реагує на загальнополітичні, міжнародні, культурні та соціальні проблеми, позаяк вища освіта дозволяє іï здобувачам критично сприймати світ [6, с. 46]. Студентські протести охопили значну частину таких країн, як: Іспанія (виступи проти режиму Ф. Франко), Велика Британія, Західна Німеччина, Японія (бастування та голодування проти війни у В’єтнамі), Італія (демонстрації проти непридатних умов навчання), Польща (проти цензури, вільних профсоюзів і впливу Комуністичних партій на молодіжні рухи) [4].

Найбільш показовау даному контексті Франція. Вразлива внутрішня політика президента Шарля де Голля, яка призвела до погіршення соціально-економічних умов життя, та війна у В'єтнамі негативно вплинули на французьке студентство. Ще одним важелем конфлікту між молоддю та владою стала непопулярна реформа національної освіти міністра Фуше [1].

У 60-х роках ХХ ст. вищі навчальні заклади Франції поділялись на три типи. Перший - багатопрофільні університети (на той час існувало п'ять факультетів: філологічних і гуманітарних наук, природничо-науковий, медичний, фармацевтичний і факультет права, який включав підготовку фахівців 3 економічних наук). Другий тип - „великі школи”, де навчалась майбутня еліта Франції. Вони випускали вузькопрофільних спеціалістів (приміром, військова справа). Третій - університетські технологічні інститути (УТІ), які готували інженерів і менеджерів. Відповідно, навчальні плани УТІ передбачали відведення більшої кількості годин на проведення практикумів та семінарських занять. Однак першорядним завданням викладачів було сприяти виробленню у студентів загальних пошукових навичок, а не навчанню відповідній професії. В планах міністра освіти була реструктуризація першого типу вищої освіти для промисловості та сфери послуг [7]. Тодішня університетська традиція, на думку Фуше, повинна була б нівелюватися: випускники ліцеїв, що отримали диплом бакалавра і колись вступали в університет без екзаменів, тепер змушені були складати конкурсні іспити. На гуманітарних факультетах вводились 
нові дисципліни, важкі для засвоєння, а стипендію отримували лише деякі абітурієнти. Було заплановано скорочення тих спеціальностей, на яких навчалось найбільше студентів, оскільки держава не могла забезпечити їм працевлаштування [1]. Саме ці провокаційні явища згодом стали одними з визначальних факторів появи французької травневої революції 1968 року. Про них і розповідає французький письменник Робер Мерль (1908-2004) у романі „За склом” (1970), на той час - викладач англійської літератури в університеті Нантера. Авторський текст показував, що система навчання у тодішній Франції була вкрай застарілою і вже малопродуктивною.

Значне збільшення кількості університетських студентів було наслідком демографічного вибуху післявоєнних років. Зважаючи на нові умови життя, дедалі більше французів намагалося отримати вищу освіту. Однак вона, як підкреслює М. Курланські, була зорієнтована на „механічне виготовлення спеціалістів”, украй неосвічених і позбавлених широти мислення [4, с. 307]. До того ж державне вище навчання було доступне через відсутність вступних іспитів. Саме тому в 1964 р. збудували університет в Нантері, що мав на меті „розвантажити” Сорбонну. Як пише Р. Мерль: „...потреба в будівництві була гостра: з 1900 по 1967 рік кількість жителів - робітників, службовців, дрібних торговців - зросла 3 п’ятнадцяти до дев'яноста п'яти тисяч чоловік” [5, с. 11].

Новий університет розташувався посеред декількох заводів, побудованих поруч, i будинків, схожих на бараки, де жили іммігранти з Португалії й Африки. Студенти були позбавлені змоги сидіти в кафе чи насолоджуватись архітектурними пам'ятками. Вони обмежувались кімнатним простором гуртожитку, де було заборонено змінювати меблі, готувати їу, говорити про політику, приводити гостей і де гостро стояло гендерне питання (хлопцям суворо заборонялося приходити в кімнати до дівчат, а дівчатам до хлопців - лише з письмового дозволу батьків) [4, с. 311]. Такі умови ще більше підсилювали вкрай нестабільну соціальну ситуацію в країні, що згодом переросла в революцію.

Тих, хто хотів здобути вищу освіту, так само, як і професорів 3 асистентами, чимраз більшало. Р. Мерль зазначає: 
Водночас у шістдесяті роки, коли столиця почала поглинати своє передмістя, Сорбонні стало тісно в іiі старих стінах. Це пояснювалося великим напливом студентів, які мусили приходити за півгодини до початку лекцій, щоб захопити (з мінімальними шансами на успіх) місце на лавах чи бодай на підлозі в аудиторії [5, с. 11].

Це негативно позначувалось на якості лекційних та семінарських занять. На сторінках роману Р. Мерля все це знайшло прямий відбиток.

Одним із типових персонажів у романі постає професор Фременкур. Під час лекцій, скаржиться він, неможливо утримувати контакт зі слухачами через їхню надмірну кількість. Потребувала оновлення й застаріла методика викладання лекційних занять цього професора: він ніколи не дискутує зі слухачами, що певною мірою виправдовує пасивність слухачів. Відсутність діалогу можна пояснити й байдужістю самих безініціативних студентів, які не наважувалися ставити дискусійні запитання. За висновком американського журналіста М. Курланські, який говорив про студентство в загальному соціологічному плані, студенти тих часів не мали можливості обговорювати будь-які проблеми зі своїми викладачами, між ними не існувало взаємозв'язку, тому й не виникало конструктивного діалогу ані в аудиторіях, ані за межами університету [4, с. 307]. Будь-які суперечки між професорами, асистентами та спудеями вирішувалися викликами поліції (зазначимо, що через нестабільні політичні події 60-х років ХХ ст. їх виникало чимало). Так, на сторінках роману зображено обурення одного з юнаків:

Замість того, щоб знайти спільну мову зі студентами шляхом переговорів, професор викликає поліцію. <..> керівництво осоромилось, довівши, що воно неспроможне навести порядок в університеті без допомоги кийка й поліції [5, с. 32].

Або ж читаємо про скандальну ситуацію 3 професором Рансе, який перед своєю лекцію категорично відмовляється надавати мікрофон (право голосу) чотирьом студентам:

...зрештою, що означає відмова надати мікрофон студентам, які хочуть зробити оголошення перед лекцією? Це означає: мікрофон 
належить мені, факультет створили для професорів, а не для студентів. А щодо вас, то ви маєте лише одне право - слухати [5, c. 45].

Ряд аналогічних дрібних фактів постає першопричиною внутрішнього бунту молоді, яка на власний кшталт намагається владнати студентсько-викладацькі протиріччя.

Претензії молоді формулювалися широко, стосувалися відсутності творчого контакту 3 викладачами, якості їхнього викладання, побутових умов університету, фінансування. Приміром, професорська лекція Фременкура про „Гамлета”, у якій він філософствує про едипів комплекс як головну проблему принца Данського, подана у відверто іронічному ракурсі. На студентський смак проблеми, які акцентувалися цим лектором, були вкрай архаїчними, безвідносними до їхніх потреб, відверто потребували оновлення.

У романі Р. Мерля предметно відтворена французька методика проведення семінарів, їі спрямованість на загал, без урахування того факту, що кожен студент є неповторною особистістю, що зрештою й провокує когнітивний дисонанс. Заняття асистента Левассера, на якому аналізувалася творчість Ж.-Ж. Руссо, було побудоване на заздалегідь підготовленій доповіді-розборі однієї з глав книги студенткою. Даніель Торонто повинна була доповідати перед групою, не читаючи з листочка. Після цього йшло обговорення ii виступу, яке закономірно перетворилось на своєрідну лекцію самого Левассера про стиль Руссо, що ніби підтверджує дратівливу для молоді другорядність студентства (пасивні слухачі).

Однак підготовка асистента до пари, описана в позитивному методологічному ключі, виглядає бездоганною. Він наперед відшліфував перед магнітофоном аналіз свого тексту, щоб без конспекту утримувати зоровий контакт з аудиторією:

...тепер, говорячи, він відчував велике задоволення. Це була чудова праця: тонко продуманий план, дотепні переходи, освітлено всі куточки й закамарки, є навіть невеличкі відкриття, - а втім, у літературній критиці ніколи не можна бути ні в чому певним, Левассер подумки брав у лапки слово „відкриття” [5, с. 55]. 
Ще однією вагомою причиною студентського незадоволення навчанням були високі вимоги до самостійної роботи всупереч реальному доступу до наукових джерел. Відповідно до навчальних планів, студентство мало самотужки доповнювати лекційний матеріал. Однак у 1960-х роках, звертаючись до бібліотек, не завжди вдається отримати потрібну книгу. Так, читаємо у романі „За склом":

Уже цілу годину Менестрель сидів у читальні над аналізом давньофранцузького тексту, що його задав Лезен. Перше розчарування - німецькі книжки, зазначені в бібліографічному списку Лезена були на руках. У кого? Звісна річ, у самого Лезена. Професори й асистенти, готуючись до лекцій, збирають усі вершки, і студентам залишається дірка від бублика. Менестрель мав у своєму розпорядженні два довідникові видання: маленький етимологічний збірник якогось Штапперса, без року видання, але напевне вельми давній, бо він дістався йому ще від батька, й досить задавнений, куплений на набережній словник Грансеня д’Отріва, надрукований на якомусь жовтуватому шорсткому туалетному папері. Цікаво, що для вивчення давньофранцузької доводиться звертатись до німецьких підручників [5, с. 58].

Отже, вимоги до оновлення вишівського навчання могли провокуватися не лише застарілою системою викладання, а й консервативними науково-технічними можливостями освіти, малодоступністю першоджерел.

Іншою причиною визрівання бунтарських настроїв паризького студентства слугувала фінансова нестабільність, позаяк менша частина часу залишалась на завдання самостійного опрацювання матеріалу через пошуки роботи. На сторінках роману це питання постає навіть у цифрах - один із героїв, раціонально аналізуючи свої прибутки, робить висновок, що для того, аби вижити, йому потрібно, передусім, багато та важко працювати:

9000 франків - кімната в гуртожитку. 140 франків - обід у кафетерії, 100 франків - сніданок, загалом на харчі близько 11000 франків на місяць. $9000+11000=20000$ франків, приблизно місячна його стипендія. До цього слід додати витрати за прання, одяг, транспорт, сигарети, газети, книжки й - хоч би час від часу - 
склянку кави в кафетерії. Якщо бути вельми ощадливим, можна вкластися в 35000 франків. Навіть позичивши в матері 40000 франків на листопад і грудень, він мусив, щоб звести кінці з кінцями, ходити на підробітки, цебто втрачати чимало годин навчання; тепер, коли затримують стипендію, а мати відмовляє йому в допомозі, доведеться витрачати втричі більше часу на підробітки, братися за найбезглуздішу роботу в Парижі. Не кажучи вже про час, що йде на дорогу, про втому, невимовну нудьгу. В першому триместрі він доставляв додому югурт, заступав у Есдера продавця, що занедужав, розбирав квитанції на поштамті, давав уроки розумово відсталій дівчинці й займався бебі-сіттінгом. Як правило, це була тяжка робота, офіційно неоформлена <..> I не стільки деморалізує нікчемність цих робіт $<\ldots>$, скільки той факт, що ти постійно опиняєшся безробітним і вічно мусиш підшукувати для себе якусь іншу роботу. <..>. Зрештою опиняєшся в безвиході, не знаючи, що страшніше: не знайти роботу й зостатись без шматка хліба чи провалитись на конкурсних іспитах через те, що ніколи було вчитися [5, с. 61-62].

Значна частина студентів відсіювалась саме за цих обставин, що давало змогу керівникам вузів справлятися з напливом молоді в університети [6].

Були проблеми й 3 організацією роботи факультетів зі студентами. Для того, щоб бути присутнім на заняттях, студент мав записатися на факультет, що відкривався кожного року (у Нантері та Парижі). Однак даний процес мав безліч нюансів: абітурієнт мусив бути жителем Паризького регіону, або отримати атестат про повну середню освіту в навчальних закладах цього академічного округу, або ж бути записаним в $1965 / 1966$ чи $1966 / 1967$ навчальних роках на один із факультетів Паризького університету, або навчатися в 1965 / 1966 рр. у державному закладі вищої освіти Парижа, або $1966 / 1967$ року бути слухачем курсів попередньої підготовки до певної з „великих шкіл” в одному з ліцеїв Паризького академічного округу [7]. Отже, пройшовши відбір, вступник розраховував на продуктивне отримання знань. Однак, як описує Р. Мерль, застаріла система викладання та сукупність інших факторів призвели до визрівання світоглядної кризи молодих вихованців. 
Автор ніби „препарує” натовп, показує, що загал - це сукупність особистостей, розгортає ряд типових образів студентського середовища. Так, студент Менестрель, який отримав статус всезнайки у своїх товаришів, скаржиться, що вивчати твір Тацита „Діалог про ораторів” не має сенсу, оскільки він не надто цікавий, особливо для тих, хто цікавиться сучасною літературою:

Ох, цей Таціт... Припустімо, його лаконізм гідний похвали, ну а зміст? Ви вважаєте, що „Діалог про ораторів” може викликати цікавість у людини, якій сповнилось двадцять у лютому 1968 року? Одна річ наламати собі руку на перекладах 3 латини, яку ти студіював дев'ять років (усупереч своїй волі), а інша - любити іiі i вірити в їі магічну силу (про яку професори говорили 3 побожною шанобливістю) [5, с. 21].

На думку героя, латинська мова, як і iї переклад, також віджила своє, тому замість неї краще вивчати російську мову i, відповідно, літературу. Отже, осучаснення потребували не лише лекції, семінари, фінансування, а й застарілі навчальні програми.

Письменник змальовує й типи викладачів, він іронізує 3 тих, які тиснуть на самостійне мислення студентів, змушують звертатися, передусім, до визнаних авторитетів, до своїх лекцій, гостро реагують, коли студентство відхилиться від заданого ними напрямку. Приміром, одна зі студенток, готуючи письмове завдання, так коментує ставлення професорів до самостійних роздумів:

...як бачиш, твої „власні думки” не повинні виходити за наперед визначені межі, ти не можеш звернути ні праворуч, ні ліворуч, мусиш рухатися тільки прямо, в напрямку, що його непомітно задали професори й критики, адже, якщо ти трудишся в поті чола над письмовою роботою, то вже не для того, щоб дістати „сім” або „вісім” з приміткою: „концепція дуже довільна” або „курйоз, що не витримує жодної критики”. В принципі ти, якщо навіть і не підлиза, не бажаєш вразити своєю письмовою роботою професора, скажімо, твоя робота - це в кращому разі компроміс між тим, що ти думаєш, і особистими поглядами професора, а це, моя голубко, і є академізм [5, с 179]. 
Кожне покоління продукує свого ідеального студента. За часів античності він повинен був всюди слідувати за своїм учителем, бути хорошим оратором і вміти полемізувати; в епоху Середньовіччя - знаходити істину та знання в Богові; в добу Просвітництва - осягати нові явища за допомогою науки та розуму. Р. Мерль синкретизував усі попередні поняття відносно справжнього студента і створив узагальнюючу модель свого часу, характеризуючи його як „запеклий читальник, пожирач книжок і преси, книжковий хробак, про все поінформований, завжди попереду, боїться, що чогось не знатиме про останній «ізм», який 3'явився на ринку" [5, с. 219].

Зауважимо, що таких студентів завжди дуже мало. Тодішня вишівська система дозволяла тим, хто навчається, не виконувати завдань, приходити на пари не підготовленими, сліпо зазубрювати матеріал, не висловлюючи власних ідей. У числі таких бачимо, приміром, Бушюта, який нічого не робить:

...досі ще не написав жодної курсової, не зробив жодного аналізу, жодного перекладу. Сидить на лекціях нічого не конспектуючи, взагалі нічого не роблячи; він би й на лекції не ходив, якби знайшов у собі сили відмовитись від них. „Гадаю, коли його татусеві набридне видавати йому щомісяця грошенята, він купить синочкові якусь крамничку, де той спатиме, забившись у куточок, тимчасом поки інші працюватимуть за нього <...”. Взагалі ж він людина поверхнева, що ніколи не замислювалась ні над винятковою безглуздістю програм і навчальної методології, ні над глупотою професорів, більше того його захоплює увесь цей непотріб - Варанс, Жан-Жак, стиль, він ладен зубрити це до скону [5, с. 123-124].

Проте не всі студенти могли розраховувати на допомогу своїх батьків. Як підтверджує розвідка історика І. Родіна, у 60-х роках XX ст. кількість французьких студентів, вихідців із малозабезпечених сімей, значно зросла. Серйозною проблемою, яка чекала на таку молодь по закінченні ВНЗ, було працевлаштування, оскільки тодішня система освіти була налаштована на підготовку викладачів та державних службовців [7], а це, відповідно, призводило до великої конкуренції на ринку парці. 
Роман „За склом” торкється також болючої теми внутрішньої субординації вишівського життя - читач простежує виразні конфліктні епізоди між асистентами та професорами Нантерського університету, які негативно відбиваються на якості та етиці викладання, втягуючи в цю орбіту й студентську молодь, яка шукає в професорсько-викладацькому колективі прихильників свого бунтарського спротиву. Структура тодішнього викладацького складу виглядала так: professeur maitre (професор), de conférence (доценти, старші викладачі), assistant (асистенти, молодша викладацька ланка). Існувала також система персональних кафедр на чолі з професорами - найвищим щаблем у викладацькій ієрархії. Асистенти та молодша викладацька ланка змушені були багато i, головне, ефективно працювати, щоб досягти вищого рангу [7]. Вони робили всю „брудну роботу”: проводили іспити, перевіряли письмові роботи, мали велике навантаження й організаційні обов'язки, отримуючи при цьому низьку заробітну плату:

...саме асистенти виконують найтяжчу роботу у відділі, а їх удесятеро більше, ніж професорів, вони мають удвічі більше годин, на них покладено перевірку всіх письмових робіт, не кажучи вже про іспити та найрізноманітніші організаційні завдання. Єдине, чим професори справді перевершують їх, - це незрівнянно вищим розміром зарплати $[5$, с. 38$]$.

Будучи сам професором, Р. Мерль делегує погляд на професора студентам - в їх сприйнятті всі вони постають зверхніми, погано вихованими, комедіантами, крикунами та психами:

Власне, про професора можна скласти собі думку ще до того, як він розтулить рот, за самою його манерою слухати студента. $€$ професори поважні, що тримаються так, ніби головують на суді. Погано вихований професор розлягається в своєму фотелі, позіхає 3 нудьги й, утупившись очима в стелю, длубається в носі. Професоркомедіант раз у раз посміхається, кривляється, зводить угору брови. Професор-псих і крикун весь час щось сердито нотує, але потім майже нічогісінько не каже про те, як минув семінар. Існує навіть професор-нахаба, який на студентку, що сидить поруч із ним, дивиться так, ніби вона продажна дівка або він збирається після лекції скористатися правом першої ночі [5, с. 54]. 
Через зверхнє ставлення до молодших викладачів викладацька еліта не обговорює з ними теми семінарів і лекцій, що у свою чергу логічно переходить у некомпетентність студентів. Професорська неповага переноситься і на молодих учених, які прагнуть отримати науковий ступінь. Письменник акцентує авторитарність академічного успіху: витративши десять років (вісімсот сторінок тексту) на написання свого критичного дослідження, аспірант створює працю, яку ніхто не читатиме, позаяк автор роботи не надто популярний і на нього ніхто не буде посилатися. Така ж сама доля чекає й на асистентів, що прагнуть здобути вчене звання професора:

По суті, між агреже, який ще не має докторського ступеня, тобто ним, Дельмоном, що працює до сьомого поту й почувається безправним кріпаком, та агреже - доктором Рансе, єдиним тут після бога владикою, лежить тільки товща дисертацій, і в даному разі добре відомо, яка саме завгрубшки і якої ваги ця цеглина - вісімсот сторінок у восьмину аркуша убогої ерудиції третьорядного автора: типовий зразок нестравного критичного дослідження про письменника, якого ніхто не читає [5, с. 38].

Реформа освіти тодішньої Франції потребувала змін. Небажання йти в ногу 3 часом, застаріла система викладання, несприятливі умови студентського навчання та існування, розбрат і особистісні конфлікти між викладачами, небажання знаходити спільну мову зі здобувачами вищої освіти, на думку автора, логічно призвели не лише до кризи внутрішнього університетського життя, a й провокаційно підживили студентські заколоти. Отже, студентські заворушення 1968 р. дали поштовх до переворотів не лише в соціально-економічній, але й освітній сфері (,Закон про орієнтацію вищої освіти” 12.11.1968 р. [1]), радикально змінивши загальну європейську систему вишівського викладання.

1. Апкарова Е. Б. Реформа образования и политический кризис 1968 г. во Франции. ПЕДАГОГИКА. 2008. № 8. С. 93-101.

2. Эйзенштадт Ш. Э. Революция и преобразование обществ. Сравнительное изучение цивилизаций / пер. с англ. А. В. Гордона; под ред. Б. С. Брасова. Москва, 1999. 416 с. 
3. Кара-Мурза С., Телегин С., Александров А., Мурашкин М. На пороге „оранжевой” революции. URL : https://www.ereading.club/book.php?book=25439.

4. Курлански М. 1968. Год, который потряс мир / пер. с англ. А. В. Короленкова, Е. Л. Семеновой. Москва, 2008. 544 с.

5. Мерль Р. За склом: роман. Київ : Молодь, 1978.328 с.

6. Мінаєв А. В. Молодіжний рух другої половини 60 -х рр. ХХ ст. в країнах Західної Європи і США: ретроспективний аналіз : дис. ... канд. істор. наук : 07.00.02. Чернівці, 2006. 204 с.

7. Родин И. В. Университеты и кризис системы высшего образования во Франции (60-е - начало 70-х гг. ХX века): дис. ... канд. истор. наук : 07.00.03. Москва, 2014. 250 с.

\title{
СИСТЕМА ОБУЧЕНИЯ КАК СОЦИАЛЬНАЯ ПРОВОКАЦИЯ: ПО РОМАНУ Р. МЕРЛЯ „ЗА СТЕКЛОМ"
}

\author{
Екатерина Федоровна Калинич \\ orcid.org/0000-0002-8263-6322 \\ katerin1210@ukr.net \\ Acпирант
}

Кафедра зарубежной литературы, теории литературы

и славянской филологии

Черновицкий национальный университет имени Юрия Федьковича

Ул. Кочюбинского, 2, 58012, г. Черновиь, Украина

Аннотация: Рассмотрены причины студенческих протестов 1968 года. Внимание акцентируется на предпосылках возникновения французской майской революции. Исследован роман Р. Мерля „За стеклом” (1970) в ключе вузовской системы обучения. Определен причинно-следственный процесс социальных событий в аспекте архаической традиции преподавания в системе вузовского обучения Франции XX в. Прослежено, что назревание потребности срочного обновления учебных программ, лекционных и семинарских занятий спровоцировало бунтарские настроения студентов. Сделан вывод, что студенческие волнения 1968-го не только изменили социально-экономическую сферу французского общества, но и существенно обновили систему вузовского преподавания.

Ключевые слова: Р. Мерль, „За стеклом”, преподаватель, студент, студенческие протесты 1968 г., кризис, высшее образование. 


\title{
EDUCATION SYSTEM AS A SOCIAL PROVOCATION IN THE NOVEL "BEHIND THE GLASS" BY ROBERT MERLE
}

\author{
Kateryna Kalynych \\ orcid.org/0000-0002-8263-6322 \\ katerin1210@ukr.net \\ Department of Foreign Literature, Literary Theory and Slavic Philology \\ Yuriy Fedkovych Chernivtsi National University \\ 2, Kotsiubynskyi Street, Chernivtsi 58012, Ukraine
}

\begin{abstract}
This article is dedicated to the crisis situation in the French system of higher education of the 1960-ies. In particular, main grounds for students' protests in 1968 have been considered: opposition to political regimes, strikes against the war in Vietnam, demonstrations against improper conditions for study and censor. The attention is focused on the background of the May Revolution in France. The novel by R. Merle "Behind the Glass" (1970) within the curriculum of the higher educational institution has been studied. It has been determined that the author distinguishes a number of typical characters of the students' and teachers' media. The cause and effect course of social events within the archaic teaching tradition in the system of higher education in France in XX century has been defined. It has been traced that the necessity of epy emergency renovation of curricula, lectures and tutorials caused rebellious mood among the students. The investigation shows that financial instability, conservative scientific and technical opportunities of education, expressive conflicts between the assistants and professors of the University of Nantes, unfavorable conditions for the students' education and existence, lack of creative cooperation with the teachers, unwillingness to come to an understanding with the students in Paris resulted in the rebellious mood among the students. Under the analysis results it has been found that epy students' rebellions in 1968 not only changed social and economic sector of the French society, but also significantly renewed higher education system of teaching.
\end{abstract}

Key words: Robert Merle, "Behind the Glass", teacher, student, student protests of 1968, crisis, higher education.

\section{References}

1. Apkarova E. B. Reforma obrazovaniia $i$ politicheskii krizis 1968 g. vo Frantsii [Education Reform and the Political Crisis of 1968 in France]. PEDAGOGIKA, 2008, no. 8, pp. 93-101. (in Russian).

2. Eisenstadt Sh. E. Revoliutsiia $i$ preobrazovanie obshchestv. Sravnitel'noe izuchenie tsivilizatsii [Revolution and the Transformation of Societies : a comparative study of civilizations]. Moscow, 1999, 416 p. (in Russian). 
3. Kara-Murza S., Telegin S., Aleksandrov A., Murashkin M. Na poroge "oranzhevoi" revoliutsii [On the Threshold of the "Orange" Revolution]. URL: https://www.e-reading.club/book.php?book=25439 (accessed 1 May 2019) (in Russian).

4. Kurlansky M. 1968. God, kotoryi potrias mir [1968: The Year that Rocked the World]. Moscow, 2008, 544 p. (in Russian).

5. Merle R. Za sklom [Behind the Glass]. Kyiv, 1978, 328 s. (in Ukrainian).

6. Minayev A. V. Molodizhnyi rukh druhoi polovyny 60-kh rr. XX st. v krainakh Zakhidnoï Ievropy i SShA: retrospektyvnyi analiz [Youth Movement in late 60's of the XXth century in Western Europe and the USA: Retrospective analysis]. PhD dissertation. Chernivtsi, 2006, 204 p. (in Ukrainian).

7. Rodin I. V. Universitety $i$ krizis sistemy vysshego obrazovaniia vo Frantsii (60-e - nachalo 70-kh gg. XX veka) [Universities and the Crisis of Higher Education in France (60s - early $70 \mathrm{~s}$ of the twentieth century)]. PhD dissertation. Moscow, 2014, 250 p. (in Russian).

\section{Suggested citation}

Kalynych K. Systema navchannia iak sotsial'na provokatsiia: za romanom R. Merlia "Za sklom" [Education System as a Social Provocation in the Novel "Behind The Glass" by Robert Merle]. Pytannia literaturoznavstva, 2019, no. 99, pp. 180-193. (in Ukrainian). doi: 10.31861/pytlit2019.99.180.

Стаття надійшла до редакції 26.05.2019 p. Стаття прийнята до друку 20.06.2019 р. 